\title{
CHANGES OF THE COLOUR, TOTAL SUGAR CONTENT AND RESPIRATION RATE OF BROCCOLI HEADS DURING SHORT-TERM STORAGE
}

\author{
ZMIANY BARWY, OGÓLNEJ ZAWARTOŚCI CUKRÓW \\ I TEMPA ODDYCHANIA RÓŻ BROKUŁU \\ W CZASIE KRÓTKOTRWAŁEGO PRZECHOWYWANIA
}

\begin{abstract}
Summary. The objective of this study was to investigate the effect of short-term storage (24-96 h) at different temperatures $\left(3^{\circ} \mathrm{C}, 16^{\circ} \mathrm{C}\right.$ and $\left.21^{\circ} \mathrm{C}\right)$ on the colour, respiration rate and total soluble sugar content in broccoli heads. The respiration rate of broccoli heads was also measured at $21^{\circ} \mathrm{C}$ during $24 \mathrm{~h}$. The results of the study revealed that the colour change (hue angle and L) was the highest in the broccoli heads kept at $3^{\circ} \mathrm{C}$ after one-day storage. On the fourth day of storage the hue value decreased at $21^{\circ} \mathrm{C}$ and brightness decreased at $3{ }^{\circ} \mathrm{C}$. The respiration rate, measured at $21^{\circ} \mathrm{C}$ during $24 \mathrm{~h}$, was the highest during the first three hours, later it decreased, and between 10 and $24 \mathrm{~h}$ it was almost at the same level. The respiration rate measured on the day of harvest at $16^{\circ} \mathrm{C}$ and $21^{\circ} \mathrm{C}$ were almost five times higher than at $3^{\circ} \mathrm{C}$. After the 24 and $96 \mathrm{~h}$ of storage, the respiration rate was similar at each of the three storage temperatures. There was a significant decrease in the total soluble sugar content only after $96 \mathrm{~h}$ of storage at the temperature of $21^{\circ} \mathrm{C}$.
\end{abstract}

Key words: Brassica oleracea var. italica, storage, hue value, respiration rate, sugars

\section{Introduction}

Broccoli (Brassica oleracea var. italica) is a very common vegetable with high nutritional value. It is highly valued due to its richness in vitamins, antioxidants, anticarcinogenic compounds (Nestle, 1998) and health-promoting phytochemicals (Yuan et al., 2010), which include vitamins $\mathrm{C}$ and $\mathrm{E}$, flavonoids, carotenoids and glucosinolates 
Kałużewicz, A., Lisiecka, J., Spiżewski, T., Krzesiński, W., Frąszczak, B., Zaworska, A. (2015). Changes of the colour, total sugar content and respiration rate of broccoli heads during short-term storage. Nauka Przyr. Technol., 9, 4, \#56. DOI: 10.17306/J.NPT.2015.4.56

(Podsędek, 2007). These compounds have gained attention because of their role in the prevention of cancer and cardiovascular diseases (Finley et al., 2000).

When harvested many vegetables are subjected to considerable stress due to the sudden disruption of energy, nutrient and hormone supplies (King et al., 1990). Within $24 \mathrm{~h}$ following the harvest expression of many senescence-related genes is induced (Eason et al., 2005; Gapper et al., 2005). The postharvest senescence of broccoli is associated with yellowing, chlorophyll degradation, accumulation of pheophytin and ascorbate decline (Costa et al., 2005; Nishikawa et al., 2003).

Respiration is at the root of compositional changes that result in deterioration of quality and closely depend on temperature (Nei et al., 2005). The suppression of respiration rate during postharvest is beneficial to maintenance of freshness and quality (Techavuthiporn et al., 2008). The respiration rate is closely related to soluble sugar content. The sugar content is dependent on the diurnal cycle. In higher plants starch is the major carbohydrate with many important functions. Starch is accumulated during the day and is remobilized at night to support continued respiration (Geiger and Servaites, 1994). According to Sulpice et al. (2009), starch is the major integrator in the regulation of plant growth. King and Morris (1994) noticed that the respiration rate of broccoli declined rapidly during the first $12 \mathrm{~h}$ after harvest. But in the literature on the subject there is little information about changes in the respiration rate during a several days' period of storage.

The aim of the study was to assess the influence of short-term storage (1-4 days) of broccoli heads at different temperatures on their colour, total soluble sugar content and respiration rate.

\section{Materials and methods}

\section{Plant material}

Two series of experiment on the influence of storage time (24-96 h) and temperature $\left(3^{\circ} \mathrm{C}, 16^{\circ} \mathrm{C}\right.$ and $\left.21^{\circ} \mathrm{C}\right)$ on physiological and chemical changes in broccoli heads were conducted in 2011. Each combination consisted of five heads. The first series was carried out from 5 to 9 September, and the other one from 19 to 23 September. The research was performed on one cultivar, 'Tiburon'. The heads for the experiments were collected from the broccoli planted on 7 July at the stage of four leaves, spaced $0.5 \times$ $0.5 \mathrm{~m}$. The experiment was established on the podzolic soil, the arable layer of which was loamy sand underlying sandy loam. The soil was tested before planting and 90 $\mathrm{kg} \cdot \mathrm{ha}^{-1}$ of $\mathrm{P}_{2} \mathrm{O}_{5}, 140 \mathrm{~kg} \cdot \mathrm{ha}^{-1}$ of $\mathrm{K}_{2} \mathrm{O}$ and $100 \mathrm{~kg} \cdot \mathrm{ha}^{-1}$ of $\mathrm{N}$ were applied before soil cultivation. Additionally, nitrogen $\left(100 \mathrm{~kg} \cdot \mathrm{ha}^{-1}\right)$ was applied in three doses in the growing season. The plants were watered when the soil water potential had exceeded $-0.04 \mathrm{MPa}$. The chemical analyses were carried out on frozen material $\left(-20^{\circ} \mathrm{C}\right)$.

\section{Colour}

The colour of the broccoli was measured with the spectrometer StellarNet Black-Comet UV-VIS on each day of storage. The determined parameters were as follows: 
Kałużewicz, A., Lisiecka, J., Spiżewski, T., Krzesiński, W., Frąszczak, B., Zaworska, A. (2015). Changes of the colour, total sugar content and respiration rate of broccoli heads during short-term storage. Nauka Przyr. Technol., 9, 4, \#56. DOI: 10.17306/J.NPT.2015.4.56

"L" - brightness, ranging from no reflection for black $(\mathrm{L}=0)$ to perfect diffuse reflection for white $(\mathrm{L}=100)$; "a" - redness, ranging from negative values for green to positive values for red; "b" - yellowness, ranging from negative values for blue to positive values for yellow. Four different positions on the surface of each broccoli head were measured. The colour was reported as hue angle $\left(\mathrm{h}^{\circ}=180^{\circ}+\tan ^{-1}(\mathrm{~b} / \mathrm{a})\right.$ when $\mathrm{a}<0$ and b $>0$ ), as previously described by Zaicovski et al. (2008).

\section{Respiration rate}

The respiration rate of broccoli was measured with the LCpro+ system (ADC BioScientific) on the basis of elimination of $\mathrm{CO}_{2}$ in darkness after harvesting of broccoli heads from the field (day of storage) and after $24 \mathrm{~h}$, and after $96 \mathrm{~h}$ of storage at the temperatures of $3{ }^{\circ} \mathrm{C}, 16^{\circ} \mathrm{C}$ and $21^{\circ} \mathrm{C}$. Additionally, the respiration rate was measured for $24 \mathrm{~h}$ at the temperature of $21^{\circ} \mathrm{C}$. All measurements were taken every minute. During the measurement of respiration the system automatically maintained the set temperature in the chamber and the content of $\mathrm{CO}_{2}$ in the air was kept at the level of $360 \mathrm{ppm}$. There were two repetitions of each measurement for all combinations.

\section{Total soluble sugar content}

In order to determine the total content of soluble sugar in broccoli heads the anthrone method was applied. It consists in extracting sugars from a $5 \mathrm{~g}$ frozen sample and adding $100 \mathrm{ml}$ of distilled water. The prepared material was placed in an MPW-251 laboratory centrifuge (Med. Instruments) for $10 \mathrm{~min}$ and centrifuged at the rotational speed of 5000 revolutions per minute. Next, $1 \mathrm{ml}$ of centrifuged solution was used for further analysis and it was filled with distilled water up to $100 \mathrm{ml}$. From the diluted solution $1 \mathrm{ml}$ was taken and placed in a test tube with $5 \mathrm{ml}$ of anthrone reagent. The anthrone reagent was obtained by dissolving $160 \mathrm{ml}$ of anthrone in $100 \mathrm{ml}$ of $80 \%$ sulphuric acid.

The extract and the reagent were placed in an MLL 547 water bath (AJL Electronic) for $10 \mathrm{~min}$ at a temperature of $90^{\circ} \mathrm{C}$. When the solution cooled down, it was tested for absorbance at $620 \mathrm{~nm}$ by means of a Genesys 10VIS spectrometer (Thermo Electron Corporation).

The percentage of sugar $(\% \mathrm{CHO})$ was calculated according to the following formula:

$$
\% \mathrm{CHO}=\frac{\mathrm{w}}{\mathrm{M}}-\frac{\mathrm{y}}{10}(\%)
$$

where: $\mathrm{w}$ - sugar concentration $\left(\mathrm{mg} \cdot \mathrm{l}^{-1}\right)$ based on absorbance measurement, read from glucose model curve, $\mathrm{y}$ - dilution $\left(\mathrm{cm}^{3}\right), \mathrm{M}$ - weight of sample for analysis $(\mathrm{mg})$.

\section{Statistical analysis}

All statistical analyses were carried out with the Stat program. The significance of the impact of temperature and duration of storage on the colour (hue angle) and brightness of broccoli and total soluble sugar content was determined with the F test. Differences between the mean values were estimated with the Duncan test at the significance level $\mathrm{P}=0.05$. 
Kałużewicz, A., Lisiecka, J., Spiżewski, T., Krzesiński, W., Frąszczak, B., Zaworska, A. (2015). Changes of the colour, total sugar content and respiration rate of broccoli heads during short-term storage. Nauka Przyr. Technol., 9, 4, \#56. DOI: 10.17306/J.NPT.2015.4.56

\section{Results and discussion}

Broccoli colour is the basic visual component of senescence (Serrano et al., 2006) and can be shown as the hue angle (Tijskens et al., 2001). According to Pramanik et al. (2006), the broccoli colour is closely related to the storage temperature and duration. The broccoli stored at the temperature of $1{ }^{\circ} \mathrm{C}$ for 7 and 14 days retained their dark green colour, whereas those stored at $20^{\circ} \mathrm{C}$ became completely yellow on the day following harvest. In our experiment during storage at the temperature of $3^{\circ} \mathrm{C}$ there was a high increase in the hue value and $\mathrm{L}$ value after the 24 hours of storage (Tables 1 and 2).

Table 1. Colour (hue angle) of broccoli heads stored at $3{ }^{\circ} \mathrm{C}, 16^{\circ} \mathrm{C}$ and $21^{\circ} \mathrm{C}$ for $24-96 \mathrm{~h}$

Tabela 1 . Ton barwy róż brokułu przechowywanych w $3{ }^{\circ} \mathrm{C}, 16^{\circ} \mathrm{C}$ i $21^{\circ} \mathrm{C}$ przez $24-96 \mathrm{~h}$

\begin{tabular}{|c|c|c|c|c|c|c|}
\hline \multirow{2}{*}{$\begin{array}{c}\text { Temperature } \\
\text { Temperatura } \\
\left({ }^{\circ} \mathrm{C}\right)\end{array}$} & \multirow{2}{*}{$\begin{array}{c}\text { Day of harvest } \\
\text { Dzień zbioru }\end{array}$} & \multicolumn{3}{|c|}{ Storage time - Czas przechowywania } & \multirow{2}{*}{\begin{tabular}{c} 
Mean \\
\cline { 3 - 6 }
\end{tabular}} \\
\cline { 5 - 7 } & $115.0 \mathrm{~cd}$ & $125.0 \mathrm{a}$ & $122.0 \mathrm{ab}$ & $122.0 \mathrm{ab}$ & $121.0 \mathrm{abc}$ & $120.9 \mathrm{a}$ \\
\hline 3 & $114.0 \mathrm{~cd}$ & $120.0 \mathrm{abc}$ & $120.0 \mathrm{abc}$ & $118.0 \mathrm{bc}$ & $116.0 \mathrm{~cd}$ & $117.5 \mathrm{~b}$ \\
21 & $118.0 \mathrm{bc}$ & $118.0 \mathrm{bc}$ & $120.0 \mathrm{abc}$ & $116.0 \mathrm{bc}$ & $110.0 \mathrm{~d}$ & $116.5 \mathrm{~b}$ \\
\hline Mean - Średnia & $115.6 \mathrm{~b}$ & $120.7 \mathrm{a}$ & $120.6 \mathrm{a}$ & $118.9 \mathrm{a}$ & $115.4 \mathrm{~b}$ & \\
\hline
\end{tabular}

*The mean values followed by the same letters do not differ significantly at $\mathrm{P}=0.05$.

*Średnie oznaczone tymi samymi literami nie różnią się istotnie przy $\mathrm{P}=0,05$.

Table 2. Brightness of broccoli heads stored at $3^{\circ} \mathrm{C}, 16^{\circ} \mathrm{C}$ and $21^{\circ} \mathrm{C}$ for $24-96 \mathrm{~h}$

Tabela 2. Jasność róż brokułu przechowywanych w $3^{\circ} \mathrm{C}, 16^{\circ} \mathrm{C}$ i $21^{\circ} \mathrm{C}$ przez $24-96 \mathrm{~h}$

\begin{tabular}{|c|c|c|c|c|c|c|}
\hline \multirow{2}{*}{$\begin{array}{c}\text { Temperature } \\
\text { Temperatura } \\
\left({ }^{\circ} \mathrm{C}\right)\end{array}$} & \multirow{2}{*}{$\begin{array}{l}\text { Day of harvest } \\
\text { Dzień zbioru }\end{array}$} & \multicolumn{4}{|c|}{ Storage time - Czas przechowywania } & \multirow{2}{*}{$\begin{array}{c}\text { Mean } \\
\text { Średnia }\end{array}$} \\
\hline & & $24 \mathrm{~h}$ & $48 \mathrm{~h}$ & $72 \mathrm{~h}$ & $96 \mathrm{~h}$ & \\
\hline 3 & $56.4 \mathrm{~d}$ & $76.3 \mathrm{a}$ & $66.2 \mathrm{bc}$ & $66.9 \mathrm{~b}$ & $58.1 \mathrm{~cd}$ & $64.8 \mathrm{a}$ \\
\hline 16 & $58.3 \mathrm{~cd}$ & $60.5 \mathrm{bcd}$ & $60.6 \mathrm{bcd}$ & $61.2 \mathrm{bcd}$ & $60.5 \mathrm{bcd}$ & $60.2 \mathrm{~b}$ \\
\hline 21 & $59.1 \mathrm{bcd}$ & $59.7 \mathrm{bcd}$ & $60.2 \mathrm{bcd}$ & $61.1 \mathrm{bcd}$ & $62.5 \mathrm{bcd}$ & $60.5 \mathrm{~b}$ \\
\hline Mean - Średnia & $57.9 \mathrm{c}$ & $65.5 \mathrm{ab}$ & $62.3 \mathrm{ab}$ & $63.02 \mathrm{ab}$ & $60.4 \mathrm{bc}$ & \\
\hline
\end{tabular}

*The mean values followed by the same letters do not differ significantly at $\mathrm{P}=0.05$.

*Średnie oznaczone tymi samymi literami nie różnią się istotnie przy $\mathrm{P}=0,05$.

This could have been caused by accumulation of anthocyans, the content of which increases due to the plant's response to the low temperature stress (Gilmour et al., 1988). Moreno et al. (2010) identified several basic anthocyanic compounds in the broccoli head. The content of the compounds largely depended on the broccoli cultivar. In the presented studies during the storage at the temperature of $3^{\circ} \mathrm{C}$ the hue value was 
Kałużewicz, A., Lisiecka, J., Spiżewski, T., Krzesiński, W., Frąszczak, B., Zaworska, A. (2015). Changes of the colour, total sugar content and respiration rate of broccoli heads during short-term storage. Nauka Przyr. Technol., 9, 4, \#56. DOI: 10.17306/J.NPT.2015.4.56

similar from the $48 \mathrm{~h}$ to the $96 \mathrm{~h}$ of storage, but the $\mathrm{L}$ value decreased. In the period from 24 to $72 \mathrm{~h}$ of storage at the temperature of $21^{\circ} \mathrm{C}$ there were no significant changes in the hue value, but after the $96 \mathrm{~h}$ of storage the hue value decreased significantly. A decrease in the hue value after $72 \mathrm{~h}$ of storage at the temperature of $20^{\circ} \mathrm{C}$ was also confirmed by Hasperué et al. (2011). DeEll and Toivonen (1999) observed a rapid decrease of the hue value after $24 \mathrm{~h}$ of storage at $18^{\circ} \mathrm{C}$. In the experiment conducted by Hasperue et al. (2011) the L value increased along with the duration of storage. Similarly, in our experiment after $96 \mathrm{~h}$ of storage at the temperatures of $16^{\circ} \mathrm{C}$ and $21^{\circ} \mathrm{C}$ the $\mathrm{L}$ value increased slightly, but the difference between its values after the individual periods of storage was not statistically significant.

Toivonen (1997) found that the change in the broccoli colour was strictly related to the respiration rate, which depended on the temperature and duration of storage. As the duration of storage at $1{ }^{\circ} \mathrm{C}$ increased, the respiration rate decreased, which reflected reduced in metabolic activity of broccoli, and, in consequence, degradation of chlorophyll. According to Nei et al. (2005) the respiration rate of broccoli in the temperature range 10 and $40^{\circ} \mathrm{C}$ decreased as time elapsed. After $9 \mathrm{~h}$ after beginning of the experiment the respiration rate was $53-84 \%$ of initial values. In the research by Finger et al. (1999) the respiration rate decreased by $50 \%$ during the first $24 \mathrm{~h}$ of storage at the temperature of $25^{\circ} \mathrm{C}$, and then it increased slightly. King and Morris (1994) arrived at similar conclusions. In their experiment, the respiration rate decreased from more than 600 $\mathrm{mg} \mathrm{CO} 2$ per $1 \mathrm{~kg} \cdot \mathrm{h}^{-1}$ to about $200 \mathrm{mg} \mathrm{CO}$ per $1 \mathrm{~kg} \cdot \mathrm{h}^{-1}$ within $24 \mathrm{~h}$. There was a different course of the respiration rate in our experiment (Fig. 1), where the measurements were taken at the temperature of $21^{\circ} \mathrm{C}$.

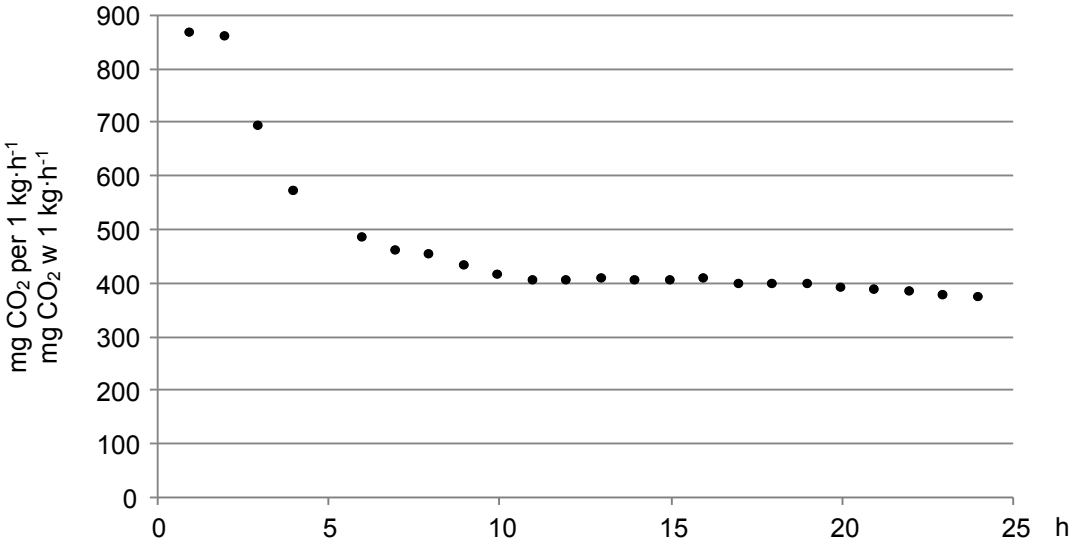

Fig. 1. Changes in the respiration rate of broccoli heads during storage at $21^{\circ} \mathrm{C}$ within $24 \mathrm{~h}$

Rys. 1. Zmiany w tempie oddychania róż brokułu w ciągu $24 \mathrm{~h}$ przechowywania w temperaturze $21^{\circ} \mathrm{C}$

The respiration rate of broccoli heads was the most intensive during the first three hours after harvesting (more than $800 \mathrm{mg} \mathrm{CO} 2$ per $1 \mathrm{~kg} \cdot \mathrm{h}^{-1}$ ), then it decreased and re- 
Kałużewicz, A., Lisiecka, J., Spiżewski, T., Krzesiński, W., Frąszczak, B., Zaworska, A. (2015). Changes of the colour, total sugar content and respiration rate of broccoli heads during short-term storage. Nauka Przyr. Technol., 9, 4, \#56. DOI: 10.17306/J.NPT.2015.4.56

mained almost at the same level (about $400 \mathrm{mg} \mathrm{CO}$ per $1 \mathrm{~kg} \cdot \mathrm{h}^{-1}$ ) from 10 to $24 \mathrm{~h}$ of storage. The differences between our findings and those reported by King and Morris (1994), and by Finger et al. (1999) may have resulted from the different size of the broccoli heads, which were measured. This correlation was also confirmed by Tian et al. (1995), who observed that the increase in the respiration rate during the first $24 \mathrm{~h}$ after harvesting was inversely proportional to the size of the broccoli head. Another dependence was noticed by Irving and Baird (1996), Seefeldt et al. (2012) and Martínez-Hernández et al. (2013) who proved that the respiration rate of the broccoli depended on the cultivar. According to Seefeldt et al. (2012) the early summer cultivar had an almost three times higher average respiration rate than late summer cultivar.

Our experiment also proved that the respiration rate at $21^{\circ} \mathrm{C}$ (Fig. 2) after the fourth day of storage was at a similar level or there was a slight increase observed in comparison to the results after the first $24 \mathrm{~h}$ of storage (Fig. 1).

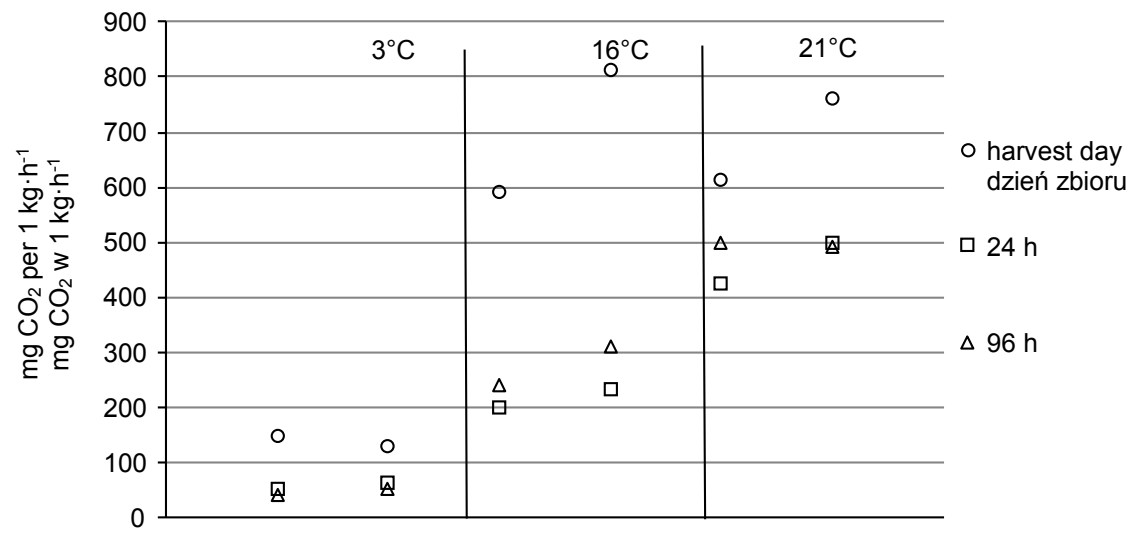

Fig. 2. Respiration rate of broccoli heads on the harvest day and after 24 and $96 \mathrm{~h}$ of storage at $3{ }^{\circ} \mathrm{C}, 16^{\circ} \mathrm{C}$ and $21^{\circ} \mathrm{C}$

Rys. 2. Tempo oddychania róż brokułu w dniu zbioru oraz po 24 i $96 \mathrm{~h}$ przechowywania w temperaturze $3^{\circ} \mathrm{C}, 16^{\circ} \mathrm{C}$ i $21^{\circ} \mathrm{C}$

The respiration rate of the broccoli heads which were placed at the temperature of $3^{\circ} \mathrm{C}$ immediately after harvest ranged from 130 to $150 \mathrm{mg} \mathrm{CO}$ per $1 \mathrm{~kg} \cdot \mathrm{h}^{-1}$. After the $24 \mathrm{~h}$ of storage the respiration rate decreased and ranged from 40 to $70 \mathrm{mg} \mathrm{CO}$ per $1 \mathrm{~kg} \cdot \mathrm{h}^{-1}$. It remained at the same level until $96 \mathrm{~h}$ of storage. The respiration rate of the heads which were placed at the temperature of $16^{\circ} \mathrm{C}$ immediately after harvest was very high. Its values were similar to the respiration rate of the heads placed at the temperature of $21^{\circ} \mathrm{C}$. After $24 \mathrm{~h}$ of storage at the temperature of $16^{\circ} \mathrm{C}$ the respiration rate decreased considerably and did not exceed $230 \mathrm{mg} \mathrm{CO}$ per $1 \mathrm{~kg} \cdot \mathrm{h}^{-1}$. After $96 \mathrm{~h}$ of storage the respiration rate was at a similar level.

In our experiment the content of sugar in broccoli heads decreased after $96 \mathrm{~h}$ of storage at the temperature of $21^{\circ} \mathrm{C}$ (Fig. 3). 
Kałużewicz, A., Lisiecka, J., Spiżewski, T., Krzesiński, W., Frąszczak, B., Zaworska, A. (2015). Changes of the colour, total sugar content and respiration rate of broccoli heads during short-term storage. Nauka Przyr. Technol., 9, 4, \#56. DOI: 10.17306/J.NPT.2015.4.56

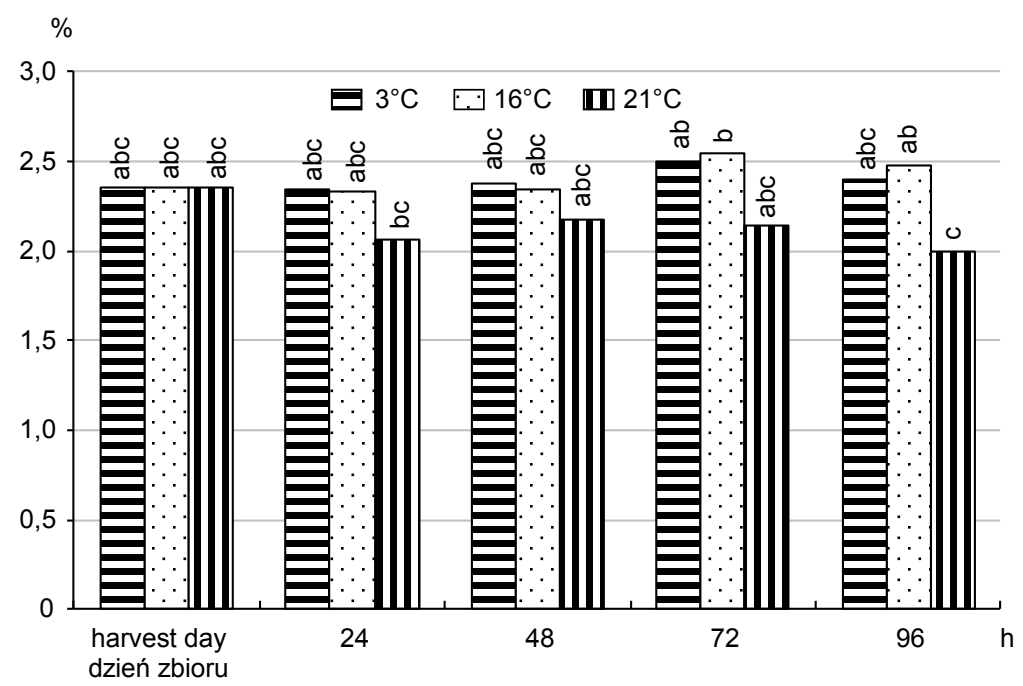

Fig. 3. Total soluble sugar content in broccoli heads during storage at $3^{\circ} \mathrm{C}$, $16^{\circ} \mathrm{C}$ and $21^{\circ} \mathrm{C}$ (the mean values followed by the same letters do not differ significantly at $\mathrm{P}=0.05$ )

Rys. 3. Ogólna zawartość cukrów w różach brokułu w czasie przechowywania w temperaturze $3^{\circ} \mathrm{C}, 16^{\circ} \mathrm{C}$ i $21^{\circ} \mathrm{C}$ (średnie oznaczone tymi samymi literami nie różnią się istotnie przy $\mathrm{P}=0,05$ )

Some authors investigated changes in the content of sugars as early as the first hours following the harvest of broccoli heads. King and Morris (1994), found a significant decrease in the content of water-soluble sugars after $6 \mathrm{~h}$ of storage, whereas Tian et al. (1997), the content decreased after $10 \mathrm{~h}$ of storage at temperature of $20^{\circ} \mathrm{C}$. Tian et al. (1997) also noticed that the content of sugar decreased very slowly during the four consecutive days. Hasperué et al. (2011), stated the variation in the content of water-soluble sugar during 5 days of storage depended on the time of the day when the heads were harvested. According to these authors, variation in the content of sugar was connected with the starch content. The sugars which are produced in the process of photosynthesis during the day are metabolised into starch. The reverse process takes place at night. After harvest starch becomes degraded rapidly and the products of degradation are metabolised into soluble sugars. Consequently, the level of water-soluble sugar in the tissues is higher for a longer period of time. This might account for the findings of our experiment, where the minimal decrease in the content of sugar was observed during the storage time.

\section{Conclusions}

1. The highest hue angle value was obtained after $96 \mathrm{~h}$ of storage at the $3^{\circ} \mathrm{C}$, whereas the brightness values after $96 \mathrm{~h}$ of storage in the tested temperatures were similar. 
Kałużewicz, A., Lisiecka, J., Spiżewski, T., Krzesiński, W., Frąszczak, B., Zaworska, A. (2015). Changes of the colour, total sugar content and respiration rate of broccoli heads during short-term storage. Nauka Przyr. Technol., 9, 4, \#56. DOI: 10.17306/J.NPT.2015.4.56

2. The higher the temperature of storage the higher the respiration rate was of broccoli heads.

3. The total soluble sugar content significantly decreased after $96 \mathrm{~h}$ of storage at $21^{\circ} \mathrm{C}$.

\section{References}

Costa, M. L., Civello, P. M., Chaves, A. R., Martínez, G. M. (2005). Effect of ethephon and 6-benzylaminopurine on chlorophyll degrading enzymes and a peroxidase-linked chlorophyll bleaching during postharvest senescence of broccoli (Brassica oleracea L.) at $20^{\circ} \mathrm{C}$. Postharvest Biol. Technol., 35, 2, 191-199.

DeEll, J. R., Toivonen, P. M. A. (1999). Chlorophyll fluorescence as an indicator of physiological changes in cold-stored broccoli after transfer to room temperature. J. Food Sci., 64, 501-503.

Eason, J. R., Ryan, D. J., Watson, L. M., Hedderley, D., Christey, M. C., Braun, R. H., Coupe, S. A. (2005). Suppresion of the cysteine protease, aleurain, delays floret senescence in Brassica oleracea. Plant Mol. Biol., 57, 645-657.

Finger, F. L., Endres, L., Mosquim, P. R., Puiatti, M. (1999). Physiological changes during postharvest senescence of broccoli. Pesqui. Agropecu. Bras., 34, 1565-1569.

Finley, J. W., Davis, C. D., Feng, Y. (2000). Selenium from high selenium broccoli protects rats from colon cancer. J. Nutr., 130, 2384-2389.

Gapper, N. E., Coupe, S. A., McKenzie, M. J., Sinclair, B. K., Lill, R. E., Jameson, P. E. (2005). Regulation of harvest-induced senescence in broccoli (Brassica oleracea var. italica) by cytokinin, ethylene, and sucrose. J. Plant Growth Regul., 24, 153-165.

Geiger, D. R., Servaites, J. C. (1994). Diurnal regulation of photosynthetic carbon metabolism in C3 plants. Annu. Rev. Plant Physiol. Plant Mol. Biol., 45, 235-256.

Gilmour, S. J., Hajela, R. K., Thomashow, M. F. (1988). Cold acclimation in Arabidopsis thaliana. Plant Physiol., 87, 745-750.

Hasperué, J. H., Chaves, A. R., Martinez, G. A. (2011). End of day harvest delays postharvest senescence of broccoli florets. Postharvest Biol. Technol., 59, 1, 64-70.

Irving, D. E., Baird, V. M. (1996). Heat production and respiration by broccoli florets during senescence at $20^{\circ}$ C. N. Z. J. Crop Hortic. Sci., 24, 199-202.

King, G. A., Morris, S. C. (1994). Early compositional changes during postharvest senescence of broccoli. J. Am. Soc. Hortic. Sci., 119, 1000-1005.

King, G. A., Woollard, D. C., Irving, D. E., Borst, W. M. (1990). Physiological changes in asparagus tips after harvest. Physiol. Plant., 80, 393-400.

Martínez-Hernández, G. B., Artés-Hernández, F., Gómez, P. A. (2013). Comparative behavior between kalian-hybrid and conventional fresh-cut broccoli throughout shelf-life. Lebensm.-Wiss. Technol., 50, 298-305.

Moreno, D. A., Pérez-Balibrea, S., Ferreres, F., Gil-Izquierdo, Á., García-Viguera, C. (2010). Acylated anthocyanins in broccoli sprouts. Food Chem., 123, 2, 358-363.

Nei, D., Uchino, T., Sakai, N., Tanaka, S.-i. (2005). Effect of high temperature on the apparent activation energy of respiration of fresh produce. Postharvest Biol. Technol., 37, 3, 277-285.

Nestle, M. (1998). Broccoli sprouts in cancer prevention. Nutr. Rev., 56, 127-130.

Nishikawa, F., Kato, M., Hyodo, M., Ikoma, Y., Sugiura, M., Yano, M. (2003). Ascorbate metabolism in harvested broccoli. J. Exp. Bot., 54, 2439-2448.

Podsędek, A. (2007). Natural antioxidants and antioxidant capacity of Brassica vegetables: a review. Lebensm.-Wiss. Technol., 40, 1-11. 
Kałużewicz, A., Lisiecka, J., Spiżewski, T., Krzesiński, W., Frąszczak, B., Zaworska, A. (2015). Changes of the colour, total sugar content and respiration rate of broccoli heads during short-term storage. Nauka Przyr. Technol., 9, 4, \#56. DOI: 10.17306/J.NPT.2015.4.56

Pramanik, B. K., Matsui, T., Suzuki, H., Kosugi, Y. (2006). Compositional and some enzymatic changes relating to sugar metabolism in broccoli during storage at $1{ }^{\circ} \mathrm{C}$ and subsequent senescence at $20^{\circ} \mathrm{C}$. ISHS Acta Hortic., 706, 219-227.

Seefeldt, H. F., Løkke, M. M., Edelenbos, M. (2012). Effect of variety and harvest time on respiration rate of broccoli florets and wild rocket salad using a novel $\mathrm{O}_{2}$ sensor. Postharvest Biol. Technol., 69, 7-14.

Serrano, M., Martinez-Romero, D., Guillén, F., Castillo, S., Valero, D. (2006). Maintenance of broccoli quality and functional properties during cold storage as affected by modified atmosphere packaging. Postharvest Biol. Technol., 39, 1, 61-68.

Sulpice, R., Pyl, E. T., Ishihara, H., Trenkamp, S., Steinfath, M., Witucka-Wall, H., Gibon, Y., Usadel, B., Poree, F., Piques, M., Von Korff, M., Steinhauser, C. M., Keurentjes, J. J. B., Guenther, M., Hoehne, M., Selbig, J., Altmann, A. R. F. T., Stitt, M. (2009). Starch, as a major integrator in the regulation of plant growth. Proc. Natl. Acad. Sci. U. S. A., 106, 10348 10353.

Techavuthiporn, Ch., Nakano, K., Maezawa, S. (2008). Prediction of ascorbic acid content in broccoli using a model equation of respiration. Postharvest Biol. Technol., 47, 3, 373-381.

Tian, M. S., Davies, L., Downs, C. G., Liu, X. F., Lill, R. E. (1995). Effects of florets maturity, cytokinin and ethylene on broccoli yellowing after harvest. Postharvest Biol. Technol., 6, 1-2, $29-40$.

Tian, M. S., Islam, T., Stevenson, D., Irving, D. (1997). Color, ethylene production, respiration, and compositional changes in broccoli dipped in hot water. J. Am. Soc. Hortic. Sci., 122, 112 116.

Tijskens, L. M. M., Schijvens, E. P. H. M., Biekman, E. S. A. (2001). Modelling the change in colour of broccoli and green beans during blanching. Innov. Food Sci. Emerg. Technol., 2, 303-313.

Toivonen, P. M. A. (1997). The effects of storage temperature, storage duration, hydro-cooling, and micro-perforated wrap on shelf life of broccoli (Brassica oleracea L., Italica Group). Postharvest Biol. Technol., 10, 1, 59-65.

Yuan, G., Sun, B., Yuan, J., Wang, Q. (2010). Effect of 1-methylcyclopropene on shelf life, visual quality, antioxidant enzymes and health-promoting compounds in broccoli florets. Food Chem., 118, 3, 774-781.

Zaicovski, C. B., Zimmerman, T., Nora, L., Nora, F. R., Silva, J. A., Rombaldi, C. V. (2008). Water stress increases cytokinin biosynthesis and delays postharvest yellowing of broccoli florets. Postharvest Biol. Technol., 49, 3, 436-439.

\section{ZMIANY BARWY, OGÓLNEJ ZAWARTOŚCI CUKRÓW I TEMPA ODDYCHANIA RÓŻ BROKUŁU W CZASIE KRÓTKOTRWAŁEGO PRZECHOWYWANIA}

Streszczenie. Celem doświadczenia było określenie wpływu krótkotrwałego przechowywania róż brokułu $(24-96 \mathrm{~h})$ w różnych temperaturach $\left(3^{\circ} \mathrm{C}, 16^{\circ} \mathrm{C}\right.$ i $\left.21^{\circ} \mathrm{C}\right)$ na ich barwę, tempo oddychania i ogólną zawartość cukrów. Dodatkowo tempo oddychania było mierzone co minutę w temperaturze $21^{\circ} \mathrm{C}$ w okresie $24 \mathrm{~h}$. Na podstawie uzyskanych wyników stwierdzono, że największa zmiana barwy (ton barwy i jasność) była po $24 \mathrm{~h}$ przechowywania w temperaturze $3^{\circ} \mathrm{C}$. Po $96 \mathrm{~h}$ przechowywania w $21^{\circ} \mathrm{C}$ zmniejszyła się istotnie wartość tonu barwy, a w $3^{\circ} \mathrm{C}$ - wartość jasności barwy. Tempo oddychania mierzone w $21^{\circ} \mathrm{C}$ przez $24 \mathrm{~h}$ było największe w ciągu pierwszych trzech godzin, później spadło i pomiędzy 10. a 24. godziną przechowywania pozostało na tym samym 
Kałużewicz, A., Lisiecka, J., Spiżewski, T., Krzesiński, W., Frąszczak, B., Zaworska, A. (2015). Changes of the colour, total sugar content and respiration rate of broccoli heads during short-term storage. Nauka Przyr. Technol., 9, 4, \#56. DOI: 10.17306/J.NPT.2015.4.56

poziomie. Tempo oddychania mierzone w dniu zbioru w temperaturze $16^{\circ} \mathrm{C}$ i $21^{\circ} \mathrm{C}$ było prawie pięciokrotnie większe niż tempo oddychania w $3^{\circ} \mathrm{C}$. Po 24 i $96 \mathrm{~h}$ przechowywania tempo oddychania miało podobną wartość $\mathrm{w}$ każdej $\mathrm{z}$ trzech temperatur przechowywania. Istotny spadek zawartości cukrów ogółem w różach brokułu stwierdzono dopiero po 96 h przechowywania w temperaturze $21^{\circ} \mathrm{C}$.

Slowa kluczowe: Brassica oleracea var. italica, przechowywanie, odcień barwy, tempo oddychania, cukry

Corresponding address - Adres do korespondencji:

Alina Kałużewicz, Katedra Warzywnictwa, Uniwersytet Przyrodniczy w Poznaniu, ul. Dąbrowskiego 159, 60-594 Poznań, Poland, e-mail: kalina@up.poznan.pl

Accepted for publication - Zaakceptowano do opublikowania:

7.08.2015

For citation - Do cytowania:

Katużewicz, A., Lisiecka, J., Spiżewski, T., Krzesiński, W., Frąszczak, B., Zaworska, A. (2015). Changes of the colour, total sugar content and respiration rate of broccoli heads during short-term storage. Nauka Przyr. Technol., 9, 4, \#56. DOI: 10.17306/J.NPT.2015.4.56 